\title{
THE CORRELATION BETWEEN OWNERSHIP STRUCTUREAND ABNORMAL RETURNS: EVIDENCE FROM TAIWAN'S SMALL AND MID-SIZED COMPANIES
}

\author{
WANG CHIEN JEN ${ }^{1}$ and LIOU YA YU ${ }^{2}$ \\ ${ }^{1}$ Associate professor of International Trade Department, Takming University of Science and Technology \\ ${ }^{2}$ International Trade Department, Takming University of Science and Technology \\ DOI: 10.46609/IJSSER.2021.v06i04.010 URL: https://doi.org/10.46609/IJSSER.2021.v06i04.010
}

\begin{abstract}
This study explores the correlation between corporate ownership structure and abnormal returns using Taiwan's small and mid-sized companies as samples. From the empirical results, we can observe the relationship that exists between firm net incomes and abnormal returns, which exhibits a significant positive relationship. This indicates that, as the net income increases, the abnormal returns will also rise. Regarding the separation of cash flow rights and voting rights, the evidence revealed an insignificant but positive influence. This is expressed in Taiwan's small and mid-size firms, wherein their cash flow rights and voting rights do not operate separately but converge. A positive influence indicates low cash flow rights, which closely relate to low abnormal returns. Meanwhile, we discovered that most of the small and mid-sized firms are family group companies. Their cash flow rights and voting rights are not exercised in a significant separate style.
\end{abstract}

Keywords:Abnormal returns, Entrenchment effects, Ownership structure, Self-interest, Voting rights

\section{Introduction}

Taiwan is an important economic entity in Asia. Investors from global institutions often invest in Taiwan's large listed companies (e.g., TSMC, DELTA, and FOXCONN) as part of their investment objectives. Most of the literature related to investment issues primarily emphasized large listed companies. However, Taiwan's economic activity is considerably active. The investment objectives of Taiwan's investors focus on- listed as well as small and mid-sized companies. Therefore, the operating performances and corporate governances of small and midsized companies also draw the attention of the investors, who expect to pursue probable abnormal returns. 


\section{International Journal of Social Science and Economic Research}

ISSN: $2455-8834$

Volume:06, Issue:04 "April 2021"

The corporate governance studies relating to the research on the relationship between insider ownership and firm value are extensive and wide-ranging. Having studied the Romanian listed companies in the Bucharest Stock Exchange, Vintila and Gherghina (2014) found a significant negative relationship between the insider shareholdings concerning firm value. Thus, they confirmed the entrenchment effects, which is opposite to the shareholders' goal of wealth maximization.

This research uses Taiwan's small and mid-sized companies as sampling firms to study the correlation between the ownership structure and abnormal returns. It also tries to understand if Taiwan's small and mid-sized firms have the entrenchment effects existing in their corporate governance, whether the entrenchment effect is more significant in these companies, and if the firms' different ownership structure affects their abnormal returns. This study may provide reference information and offer suggestions to those public investors who want to purchase the low stock prices of small and mid-sized companies as investment objectives to increase their profits in the future.

The numerous studies conducted on the roles and functions of modern companies are based on the assumption of widely dispersed ownership (Grossman and Hart, 1980). Claessens, Djankov and Lang (2000) estimated the separation of ownership and control and found that among the sampling companies in Asian countries, the voting rights often exceeded the cash flow rights. Meanwhile, through the structure of pyramid and cross holdings, the control rights of companies will be enhanced. Thus, the voting rights may continuingly exceed the cash flow rights. Further, over two-thirds of the companies are controlled by a single shareholder, and firm managers are more inclined to be the relatives of the controlling shareholders. The older companies are generally controlled by a family group. Notably, when it comes to firm management, the separation of ownership and control rights seems rare in East Asian countries. Approximately $60 \%$ of firms' top managements closely corresponded with the families of controlling shareholders. This finding highlights that controlling shareholders probably have the ability and incentives to expropriate the minority shareholders of firms (Claessens Fan, Djankov and Lang, 1999). Additionally, Claessens, Djankov, and Lang (2000) discovered that over 50\% of East Asian Corporations are extensively family controlled. The small-sized firms are also inclined toward being family controlled. However, there are some evidences in specific countries wherein the concentration of control rights gradually diminished and was accompanied by the enhancement of the countries' economic development. Having documented many studies that have estimated the operating performances of East Asian firms for 40 years, Rodrile (1997) found that the issues of firm ownership structure and separation of ownership structure and control rights remain unclear. He found the issues to have evolved over time. 


\section{International Journal of Social Science and Economic Research}

ISSN: $2455-8834$

Volume:06, Issue:04 "April 2021"

Partial literature found that a nonlinear relationship is expected between insider ownership and firm value. For instance, Han and Suk (1998) declared that, as insider holdings start to increase, a positive relationship between the levels of insider ownership and stock return is identified. However, when the insider ownership is considerably high, the interests of insiders are not consistent with that of the outsider shareholders, and the influence on firm value is negative. They found the relationship between ownership structure and firm value to be not monotonic.

Thus, the conclusions of previous studies remain unclear. Does the separation of ownership and control still exist? Are there differences between the East Asia companies? Do these differences vary from one firm to another and based on size? There still needs more research to get clarity on whether the difference in ownership structure has various impacts on the abnormal returns in large listed companies and small and mid-sized companies. Further, it is important to consider finding out the level of ownership structure and the control accompanied by the entrenchment effect that will discount firm value. In particular, the countries have an insufficient corporate governance mechanism and have weak institutional development. All these issues need to be studied in detail for sufficient clarification. The empirical results of our paper evidenced similar conclusions as those made by Claessens, Djankov and Lang (2000). They are depicted as follows. We tried to study the correlation between corporate ownership structure and earnings informativeness by using Taiwan's small and mid-sized companies as sampling companies. Consistent with the findings of Claessens, Djankov and Lang (2000), our evidence showed a significant negative effect on voting rights, which indicates that, when the large shareholders (controlling shareholders) own larger voting rights in a company, the abnormal returns decrease. This situation implies that when the controlling voting of a single family becomes stronger, it probably becomes self-interest and thus brings out the entrenchment effects of controlling shareholders. In the long run, it will expropriate the rights and equity of minority shareholders and thus decrease the abnormal returns. In addition, regarding the separation of cash flow rights and voting rights, the evidence reveals an insignificant but positive influence. This is indicated in Taiwan's small and mid-sized companies; while their cash flow rights and voting rights are not separate, they do converge. Meanwhile, a positive influence indicates that low cash flow rights are closely related to low abnormal returns. Further, the entrenchment effects might probably exist for small and mid-sized companies and might even exceed the reputation effects. It is defined as a reputation effect when companies obtain an evaluation of high reputation, which, in turn, has a positive effect on the raising of funds and selling of products. However, companies with low reputations will probably face falling stock prices, and would find it uneasy to raise funds and sell products. If the reputation is formalized, companies are required to utilize to perform the continuing activities (Cabral, 2000). According to the empirical results of our study, we suggest investors choose small and mid-sized companies as their investment portfolio, be 


\section{International Journal of Social Science and Economic Research}

ISSN: $2455-8834$

Volume:06, Issue:04 "April 2021"

prudent and consider the entrenchment effects,- ensure healthy corporate governance, and maintain the quality of financial reporting to prevent probable financial losses in the future.

The remainder of this paper is organized as follows. Section 2 presents the methodology and data. Section 3 presents the empirical results. Finally, section 4 concludes the study.

\section{Methodology and Data}

This study primarily examined the correlation between the ownership structure and earning informativeness of Taiwan's small and mid-sized companies. Claessens, Djankov and Lang (2000) analysis of firms' cash flow and control rights defines ownership to be based on cash flow rights and control rights to be based on voting rights. By bringing out the differences between cash-flow rights and voting rights, which may be divided into pyramiding and crossing holding schemes, we found large and obvious differences between these two schemes. While pyramiding schemes indicate that firms' cash flow rights exceed their voting rights, crossing holding schemes indicate that firms' voting rights exceed their cash flow rights. For instance, in approximately $80 \%$ of the listed companies in Korea and Malaysia, the top management owns significant controlling rights that belong to the controlling group. However, in Japan, the correspondence between management and controlling rights is insignificant. Lesser than $50 \%$ of the managers belong to the controlling owners of companies. Claessens, Djankov and Lang(2000) also speculated the East Asia companies to understand the relationship between ownership structure and earnings informativeness and considered the effect of firm entrenchment. Our study modified the model of ClaessensDjankov and Lang(2000) to estimate Taiwan's small and mid-sized companies. We adopt abnormal returns as the dependent variable and examine the association between abnormal returns $(A R)$, voting rights of the largest shareholder, and the separation of cash flow and voting rights ( $C V$ ratio) of the largest shareholder to understand if a firm witnessed the entrenchment effect. The independent variables include firm net income, company size, Tobin's $Q$ ratio, debt ratio, the voting rights of the largest shareholder, and the $C V$ ratio of the largest shareholder (indicating the entrenchment effects of a firm). These variables are considered to perform the respective empirical estimations. Given the relevant variables, the empirical model is formulated as shown in Eq. (1), which is as follows.

$$
\begin{aligned}
A R_{i, t}=\alpha_{1}+ & \beta_{1} N I_{i, t}+\beta_{2} N I^{*} S Z_{i, t}+\beta_{3} N I^{*} T B Q_{i, t}+\beta_{4} N I^{*} L E V_{i, t}+\beta_{5} N I^{*} V_{i, t}+\beta_{6} N I^{*} C V_{i, t} \\
& +\mu_{i, t}
\end{aligned}
$$

The dependent variable- $A R_{i, t}$ represents the abnormal returns of a company $i$ at period $t$. The independent variables include six variables. $N I_{i, t}$ indicates the net incomes of company $i$ at period t. $S Z_{i, t}$ represents the size of company $i$ in quarter $t . T B Q_{i, t}$ indicates the Tobin's $Q$ ratio, which is 
International Journal of Social Science and Economic Research

ISSN: 2455-8834

Volume:06, Issue:04 "April 2021"

calculated by having the market value divided by book value, and represents the operating performance and ability of the managers of company $i$ in quarter $t . L E V_{i, t}$ represents firm risk, which is calculated by having the total debts divided by the total assets of company $i$ in quarter $t . V_{i, t}$ represents the voting rights of the largest shareholders, which is used to estimate the control rights of the firm's largest shareholders. $C V_{i, t}$ is calculated by having the cash flow divided by the voting rights of company $i$ at period $t$. This variable is used to estimate the separation of cash flow and voting rights and represents the influence of a firm's entrenchment effects on firm value. This is to estimate the impact of entrenchment effect on the abnormal returns of Taiwan's small and mid-sized companies. $\mu_{i, t}$ is the disturbance term.

This study employs pooled estimation regression, which combines the cross-sectional and longitudinal data. Its methodology includes the fixed-effects model (FEM) and the randomeffects model (REM) and uses the Hausman test to judge the suitability of the models. This method yields reliable coefficient estimates when unobservable, individual, fixed, or random effects exist. We sampled the shares of Taiwan's small and mid-sized companies, and the study period ranged from Q1 2010 to Q3 2019. The sample period excludes the period of Q4 2019, which was the start of the global COVID-19 epidemic. We expect to observe a significant influence of the entrenchment effects of Taiwan's small and mid-sized companies. After removing the incomplete and outlier data, 269 observations remained. The data were extracted from the Taiwan Economic Journal databank. Table 1 illustrates the definition and measurement of data.

\section{Table 1 Data Definition and Measurement-Taiwan Small and Mid-Sized Companies}

\begin{tabular}{|c|c|c|c|}
\hline Notation & Variable & Measurement & Source \\
\hline$A R_{i, t}$ & $\begin{array}{l}\text { The Level } \\
\text { of Company } \\
\text { Abnormal } \\
\text { Returns }\end{array}$ & $\begin{array}{c}\text { Company abnormal returns of } \\
\text { period } t\end{array}$ & $T E J$ \\
\hline$N I_{i, t}$ & Net Income & Company Net Incomes & $T E J$ \\
\hline$S Z_{i, t}$ & $\begin{array}{l}\text { Company } \\
\text { Size }\end{array}$ & Equity of Market Value & $T E J$ \\
\hline$T B Q_{i, t}$ & $\begin{array}{l}\text { Tobin's } Q \\
\text { ratio }\end{array}$ & $\begin{array}{c}\text { Market value divided by Book } \\
\text { value }\end{array}$ & $T E J$ \\
\hline$V_{i, t}$ & $\begin{array}{l}\text { Voting } \\
\text { rights }\end{array}$ & $\begin{array}{l}\text { the voting rights of the largest } \\
\text { shareholder }\end{array}$ & $T E J$ \\
\hline
\end{tabular}


International Journal of Social Science and Economic Research

ISSN: 2455-8834

Volume:06, Issue:04 "April 2021"

$\begin{array}{cccc}C V_{i, t} & C V \text { ratio } & \begin{array}{c}\text { the } C V \text { ratio of the largest } \\ \text { shareholder (cash flow rights } \\ \text { divided by voting rights) }\end{array} & \text { TEJ } \\ L E V_{i, t} & \begin{array}{c}\text { Debt Ratio } \\ \text { of company }\end{array} & \begin{array}{c}\text { The total debts divided by total } \\ \text { assets of the company }\end{array} & T E J\end{array}$

\section{Empirical Results}

This study uses Taiwan's small and mid-sized companies falling under the NTD 10 billion market capitalization to explore if the entrenchment effects exist in Taiwan's small and mid-sized companies and determine the entrenchment effects' impact on abnormal returns. In this section, we present and discuss the estimation results of the regression equation shown in Eq. (1). We begin our analysis by testing the association of company ownership structure and abnormal returns for Taiwan's small and mid-sized companies using six variables. Tables2and 3 individually summarize the panel regression estimation results. Table 2 summarizes the estimation results of the impacts of net incomes on the abnormal returns of the respective companies during the time interval Q1 2010 to Q3 2019. Table 3 summarizes the estimation results of the individual variables during the time interval Q1 2010 to Q3 2019. The Hausman test of the two tables showed that the FEM provides the greatest explanatory power.

Table 2 Estimation Results of Panel Regression - Taiwan Small and Mid-Sized Companies

\begin{tabular}{|c|c|c|}
\hline \multicolumn{3}{|c|}{ Dependent Variable $-A R_{i, t}$} \\
\hline \multicolumn{3}{|c|}{ Fixed-Effects Model } \\
\hline Explanatory Variable & Coefficient & Coefficient \\
\hline Cons $\tan t$ & 20.176 & $\begin{array}{l}-1.463 \\
(-0.10)\end{array}$ \\
\hline$N I_{i, t}$ & $\begin{array}{c}(29.03) \\
5.835^{*} * * \\
(3.07)\end{array}$ & $\begin{array}{c}(-0.10) \\
1.0002^{*} \\
(0.64)\end{array}$ \\
\hline Observations & 269 & 269 \\
\hline AdjustedR ${ }^{2}$ & 0.0715 & 0.0573 \\
\hline$F$-statistic & $9.40 * * *(0.002)$ & $8.62(0.1958)$ \\
\hline \multicolumn{2}{|l|}{ Hausman test $x^{2}(6)$} & \\
\hline \multicolumn{3}{|c|}{$\begin{array}{l}\text { Notes:Dependent variable is company abnormal returns of Taiwan's small and mid-sized } \\
\text { companies. Time period is Q1 } 2010 \text { to Q3 } 2019 \text {. The testing results show that Fixed } \\
\text { Effects Model }(F E M) \text { has the largest explanatory power. The figures in parentheses are } t \text { - } \\
\text { statistics. *significant at } 10 \% \text { level; **significant at } 5 \% \text { level; ***significant at } 1 \% \text { level. }\end{array}$} \\
\hline
\end{tabular}


International Journal of Social Science and Economic Research

ISSN: 2455-8834

Volume:06, Issue:04 "April 2021"

Table 3 Estimation Results of Panel Regression - Taiwan Small and Mid-Sized Companies

\begin{tabular}{ccc}
\hline \multicolumn{3}{c}{ Dependent Variable $-A R_{i, t}$} \\
\hline & Fixed-Effects Model & Random-Effects Model \\
\hline Explanatory Variable & Coefficient & Coefficient \\
\hline Cons $\tan t$ & 22.286 & 16.203 \\
& $(17.22)$ & $(12.28)$ \\
\hline$N I_{i, t}$ & $42.263^{* * *}$ & $-12.535^{* *}$ \\
& $(6.86)$ & $(-1.96)$ \\
\hline$N I^{*} S Z_{i, t}$ & $-0.533^{* * *}$ & 0.0001 \\
& $(-7.23)$ & $(0.00)$ \\
\hline$N I^{*} T B Q_{i, t}$ & $-3.251^{* * *}$ & $-3.898^{* * *}$ \\
& $(-11.22)$ & $(-10.81)$ \\
\hline$N I^{*}{ }^{*} V_{i, t}$ & 0.034 & 0.087 \\
& $(0.57)$ & $(1.12)$ \\
\hline$N I^{*} V_{i, t}$ & $-0.479^{* * *}$ & $-0.503^{* * *}$ \\
& $(-3.37)$ & $(-3.27)$ \\
\hline$N I^{*} C V_{i, t}$ & 0.008 & $(2.03)$ \\
\hline Observations & $(17.22)$ & 269 \\
\hline Adjusted ${ }^{2}$ & 269 & 0.4763 \\
\hline$F$-statistic & 0.068 & $238.26(0.000)$ \\
\hline Hausman test $x^{2}(6)$ & $35.16^{* * *}(0.000)$ & \\
\hline
\end{tabular}

Notes:Dependent variable is company abnormal returns of Taiwan's small and mid-sized companies. Time period is Q1 2010 to Q3 2019. The testing results show that Fixed Effects Model (FEM) has the largest explanatory power. The figures in parentheses are $t$ statistics. *significant at $10 \%$ level; **significant at $5 \%$ level; ***significant at $1 \%$ level.

The literature finds both cash flow (representing ownership) and voting rights (representing control) to be extremely important. However, the incentives of expropriate will vary according to the differences in cash flow rights (Jensen and Mecking, 1976). Taylor (1998) observes that the ownership structure and control rights are still in evolution. Previous studies remain unclear as to whether- there are differences in the separation of control and ownership rights. They also do not provide clarity about the percentage of companies in Asia that are concentrated and controlled by few family groups. There is a need for more empirical studies to develop a better understanding of the abovementioned points. Furthermore, there is a need to understand the differences that exist between the various sizes of large listed companies and small and mid-sized companies in Taiwan. 


\section{International Journal of Social Science and Economic Research}

ISSN: $2455-8834$

Volume:06, Issue:04 "April 2021"

This study attempted to explore the correlation between corporate ownership structure and earnings informativeness using Taiwan's small and mid-sized companies as samples. We use time series panel data to perform the estimation and analysis. The empirical results are depicted as follows. In Table 2, we can observe the relationship that exists between firm net incomes and abnormal returns, which exhibits a significant positive relationship. This indicates that, as the net income increases, the abnormal returns will also rise in Taiwan's small and mid-sized firms. This phenomenon is consistent with our previous expectation. This study further examines whether the separation of ownership structure and control rights vary significantly based on firm size. Regarding the effect of firm size on abnormal returns, the evidence expresses a significant negative influence. This indicates that, as a firm's size increases, the abnormal returns decrease. Tobin's $Q$ ratio indicates the company growing prospect, which is calculated by having the market value divided by book value. However, the evidence presents a significant negative effect. McConnell and Servaes (1990) observe that, at low levels of insider ownership, an increase in insider ownership also increases- Tobin's $Q$ ratio. However, at high levels of insider ownership, the scenario is different. They acknowledged the positive relationship that exists between insider ownership and firm value. That is, as Tobin's $Q$ ratio rises, there is a fall in the abnormal returns of Taiwan's small and mid-sized companies. From the significant negative influence of firm size and Tobin's $Q$ ratio, we can see that the main reason probably is that Taiwan's small and mid-sized firms belong much more to family group enterprise. When the controlling rights of controlling shareholders become larger, which probably formalizes the entrenchment effects in the long run, the firms' stock returns will fall and move downward. Our empirical results are inconsistent with those of Claessens, Djankov and Lang (2000). The main reason for this probably is that our researching object is the correlation between ownership structure and abnormal returns of Taiwan's small and mid-sized companies, while Claessens, Djankov and Lang (2000) primarily focused on studying the large listed companies. In the debts ratio, this has an insignificant influence. This evidence exhibits the small and mid-sized firms loaned from the banks by using high leverage in business operation. However, the results show that the debts cannot produce any significant positive effect on the abnormal returns. The main reason for this, perhaps, is that the way the loans are used from banks is mixed. Thus, an attempt to produce the effect on abnormal returns also remains insignificant. In the effects of voting rights, this evidence showed a significant negative effect, which indicates that, when the largest shareholders (controlling shareholders) own larger voting rights, the abnormal returns decrease. This situation implies that when the controlling voting rights of a single-family group become stronger, it probably becomes more self-interested and exhibits the entrenchment of the controlling shareholders. For the self-interest of the largest shareholder, family -group companies may probably move their funds to foreign countries to evade tax. In the long run, this entrenchment behavior will expropriate the rights and equities of the small shareholders, thus 


\section{International Journal of Social Science and Economic Research}

ISSN: $2455-8834$

Volume:06, Issue:04 "April 2021"

decreasing the firm abnormal returns. Finally, regarding the separation of cash flow rights and voting rights, the evidence revealed an insignificant but positive influence. This is expressed in Taiwan's small and mid-size firms, wherein their cash flow rights and voting rights do not operate separately but converge. Meanwhile, a positive influence indicates low cash flow rights, which closely relate to low abnormal returns. However, we discovered that most of the small and mid-sized firms are family group companies. Their cash flow rights and voting rights are not exercised in a significant separate style. Taiwan's small and mid-sized firms might probably witness the entrenchment effect, and this, moreover, might exceed the reputation effect. Companies have not yet obtained the evaluation of high reputation regarding the raising of funds, selling of products, or the rising stock prices.

Classens, Djankov and Lang (2000) found 41 of the 66 (62.12\%) Malaysian companies belonging to family groups and, 67 of the 99 (67.68\%) Thailand companies belonging to family groups. This study arrived at a similar conclusion and is consistent with the study of Classens, Djankov and Lang. The relationship between the ownership structure and firm returns is much more like a U-shape relationship. That is, after firms grow up in a certain period, most firms produce the entrenchment effects, which will eventually make the abnormal returns downward move downward and fall. The empirical results of our study reveal that, since Taiwan's small and mid-sized companies are probably dominated by single- family groups, as firms' net incomes rise, the abnormal returns do not increase accordingly. This situation also explained the reasonwhy most institutional investors prefer investing in publicly traded listed companies as their investment objectives and not in small companies. The investors probably are hesitant and have an uncertain intention when it comes to the entrenchment effects produced by small firms.

\section{Conclusion}

The influence of ownership structure on firm value still needs extensive researching. The roles of the largest shareholders are emphasized because they draw much more attention from the public investors. Regarding the East Asian companies, previous studies relating to the sphere of corporate governance have left some of the questions unanswered. Thus, to separate the ownership and control rights, estimate the evidence, and understand the relationship of insiders' ownership, the corporate performance is still necessary. This study explores the correlation between insider ownership and earning informativeness by using Taiwan's small and mid-sized companies as the sampling companies. The empirical results show that there is a significant positive relationship between the firms' net incomes and abnormal returns. This indicates that when the net income of small and mid-sized companies increases, the abnormal returns will also increase. However, the relationship between the firm size and abnormal returns reveals a significant negative influence, indicating that when the firm size of small and mid-sized companies increases, their abnormal returns decrease. The primary reason for this is probably 


\section{International Journal of Social Science and Economic Research}

ISSN: $2455-8834$

Volume:06, Issue:04 "April 2021"

that most of Taiwan's small and mid-sized firms belonged to family group enterprises. As the controlling rights of the controlling shareholders become large and dominated, they may produce the entrenchment effects to make the stock prices and earnings move in the downward direction in the long run.

Claessens, Djankov Fan and Lang (2002) disentangled the incentive and entrenchment behavior of the large shareholders. They found that when the cash flow ownership of large shareholders increases, the firm value increases as well. The correlation expresses a positive incentive effect. However, when the control rights exceed the cash flow rights, the firm value will fall and exhibit an entrenchment effect. Our study found similar empirical results as those found by Claessens, Djankov Fan and Lang (2002). That is, as the large shareholders take control of the cash flow rights to a degree, the firm value and Tobin's $Q$ ratio will fall and exhibit entrenchment effects on Taiwan's small and mid-sized companies. Regarding the voting rights, our evidence reveals a significant negative influence. This indicates that when the controlling shareholders own larger voting rights, the stock prices of Taiwan's small and mid-sized firms decrease. This situation shows that, as the controlling rights of a single family become larger, a probable reason for this is the self-interest and the entrenchment effects. Another reason is that the largest shareholders of family companies probably move their funds to other foreign countries to evade tax. By estimating the separation of cash flow rights and voting rights, the evidence exhibits a positive but insignificant influence. This indicates that there is an insignificant separation of cash flow rights and voting rights that exist in Taiwan's small and mid-sized companies, but they exist in a converging style. As the firm wealth is concentrated in the hands of few families, we can observe that the entrenchment effects exist in most East Asian companies. However, the situation of wealth concentration may influence corporate governance, information transparency, law progress, institutional framework, and economic activity, which may produce development obstacles to the political and economic policies of the respective countries in the future. This study offers referring information that, when the investors choose stocks for their investment portfolio, they still need to be prudent in considering if the small and mid-sized firms have significant entrenchment behaviors, quality corporate governance, and sound financial reporting to prevent financial losses in the future.

\section{References}

[1] Cabral, L.M.B.,"Stretching Firm and Brand Reputation,"RAND Journal of Economics, 31, pp.658-673, 2000.

[2] Claessens, S., S. Djankov and L. H. P. Lang, "The Separation of Ownership and Control in East Asian Corporations,"Journal of Financial Economics, 58, pp.81-112, 2000. 
International Journal of Social Science and Economic Research

ISSN: 2455-8834

Volume:06, Issue:04 "April 2021"

[3] Claessens, S., S. Djankov, J. P. H. Fan and L. H. P. Lang, "Disentangling the Incentive and Entrenchment Effects of Large Shareholdings,”Journal of Finance, 57, pp.2741-2771, 2002.

[4] Claessens, S., Fan, J.P.H., Djankov, S., Lang, L.H.P., "on Expropriation of Minority Shareholders: Evidence from East Asia,"Policy Research Paper 2088. World Bank, Washington DC, 1999.

[5] Grossman, S., and Hart, O., "The Costs and Benefits of Ownership: a Theory of Vertical and Lateral Integration,"Journal of Political Economics, 94, pp.691-719, 1986.

[6] Han, K.C., and Suk, D.Y.,"The Effect of Ownership Structure on Firm Performance: Additional Evidence," Review of Financial Economics, 7(2), pp.143-155, 1998.

[7] Jensen, M.C., and Meckling, W.H., "Theory of the Firm: Managerial Behavior, Agency Costs and Ownership Structure,"Journal of Financial Economics, 3(4), pp.305-360, 1976.

[8] McConnell, J.J., Servaes, H.,"Additional Evidence on Equity Ownership and Corporate Value,"Journal of Financial Economics, 27(2), pp.595-612, 1990.

[9] Rodrik, D., “The Paradoxes of the Successful State,'European Economic Review, 41, pp.441442, 1997.

[10] Taylor, M., "Have cash, will travel: Hong Kong is no longer big enough for property tycoon Li Ka-Shing,"Far Eastern Economic Review March 5, pp.56-60, 1998.

[11] Vintila G. and Gherghina S. C., "Insider Ownership and the Value of the Bucharest Stock Exchange Listed Companies: Convergence-of-Interest or Entrenchment Effect?” International Journal of Economics and Financial Issues, .4(1), pp.183-195, 2014. 